Considerable evidence exists to support the concept of increased shunting in the foot of diabetics, ${ }^{10}$ but the exaggeration of this abnormality in the dependent position is a new observation.

Several inferences may be drawn from this study. Failure of precapillary vasoconstriction on dependency will result in the capillary bed being exposed to a greater hydrostatic load. This may account for the development of peripheral oedema seen in patients with neuropathy. Furthermore, chronic exposure to capillary hypertension may act as a localising stimulus to thickening of capillary basement membranes. Vracko described increasing thickness of capillary basement membrane from thigh to foot, which is particularly pronounced in patients with diabetes. ${ }^{13}$ Both these inferences require direct experimentation to substantiate them. Preliminary results from our laboratory suggest that capillary pressure is indeed higher in the dependent foot of diabetics compared with normal subjects.

We thank Dr Peter Wise and Dr P B Fowler for allowing us to study their patients, and Professor Laurence Smaje for helpful advice. GR was supported by the North West Thames Regional Health Authority on a locally organised research grant, and JET by a Wellcome Trust senior lectureship.

\section{References}

1 Levick JR, Michel CC. The effects of position and skin temperature on the capillary pressures in the fingers and toes. F Physiol (Lond) 1978;274:97-109.

2 Hendriksen O. Local reflex in microcirculation in human subcutaneous tissue. Acta Physiol Scand 1976;97:447-56

3 Martin MM. Diabetic neuropathy. Brain 1953;76:594-625.

4 Edmonds ME, Archer AG, Watkins PJ. Ephedrine: a new treatment of diabetic neuropathic oedema. Lancet 1983;i:548-51.

5 Williamson JR, Kilo C. Current status of capillary basement-membrane disease in diabetes mellitus. Diabetes 1977;26:65-73.

6 Bloom S, Till S, Sonksen P, Smith S. Use of a biothesiometer to measure individual vibration thresholds and their variation in 519 non-diabetic subjects. $\mathrm{Br} \mathrm{Med} \mathrm{f} \mathrm{1984;288:1793-5.}$

7 Ewing DJ, Clarke BF. Diagnosis and management of diabetic autonomic neuropathy. Br Med $\mathcal{J}$ 1982;285:916-8.

8 Nilsson GE, Tenland T, Obert PA. A new instrument for continuous measurement of tissue blood flow by light beating spectroscopy. IEEE. Trans Biomed Eng 1980;27:12-9.

9 Tooke JE, Ostergren J, Fagrell B. Synchronous assessment of human skin microcirculation by laser Doppler flowmetry and dynamic capillaroscopy. Int I Microcirc Clin Exp 1983;2:277-84.

10 Ward JD. The diabetic leg. Diabetologia 1982;22:141-7.

11 Archer AG, Roberts VC, Watkins PJ. Blood flow patterns in painful diabetic neuropathy. Diabetologia 1984;27:563-7.

12 Watkins PJ, Edmonds ME. Sympathetic nerve failure in diabetes. Diabetologia 1983;25:73-7.

13 Vracko R. Skeletal muscle capillaries in diabetics. Circulation 1970;41:271-83.

\title{
Iron deficiency in young Bradford children from different ethnic groups
}

\section{P EHRHARDT}

\begin{abstract}
Haematological parameters and iron state were studied in children admitted to hospital consecutively during a six month period. A total of 147 of 598 children $(24.6 \%)$ were anaemic, with haemoglobin values below the third centile of the reference range, and 131 of 400 children (32.8\%) were iron deficient, with serum ferritin concentrations less than $10 \mu \mathrm{g} / \mathrm{l}$. Both findings were more common in children from the Asian ethnic minority.

The "routine" full blood count is a useful tool for the presumptive identification of iron deficiency in childhood. Iron deficiency is deleterious to the health of young children. In view of its extent and degree-not exclusively among the Asian ethnic minority-a community based preventive programme on the lines of the Stop Rickets Campaign is recommended.
\end{abstract}

\section{Introduction}

Iron deficiency is common among young children and is usually determined nutritionally. ${ }^{12}$ Many young children are admitted to hospital, and those of poorer socioeconomic state are overrepresented among these.

Bradford Health Authority serves a population of 340000 , which includes an Asian ethnic minority of about 60000 . These consist of first and second generation migrants, almost entirely Moslems from Pakistan, with small numbers of Moslems from Bangladesh, Hindus, and Sikhs. Roughly one third of children admitted to Bradford paediatric beds are from the Asian ethnic minority.

Bradford Children's Hospital, Bradford, West Yorkshire BD8 7QF

P EHRHARDT, MB, MRCP, senior registrar

Correspondence to: Clarendon Wing, General Infirmary at Leeds, Leeds LS2 9NS
This report presents the haematological results and serum concentrations of the iron storage protein ferritin in children consecutively admitted to paediatric beds over six months. The children studied were aged between 6 months and 4 years. Anaemia, hypochromia, microcytosis, and iron deficiency were common findings.

\section{Patients and methods}

Every child admitted to a paediatric bed in Bradford during 1 September 1983 to 29 February 1984 was eligible for study if the age on the date of admission was at least 6 months and less than 4 years. Children admitted more than once were studied during the initial admission. The study was approved by the ethical committee.

In those children in whom a venepuncture was thought clinically necessary blood was taken for full blood count (Coulter counter method) and serum ferritin estimation (by immunoradiometric assay) in addition to clinically indicated assays. Haemoglobin electrophoresis was performed on any child whose mean corpuscular haemoglobin value was less than $25 \mathrm{pg}$.

The following children were excluded: six with $\beta$ thalassaemia, three in whom $\beta$ thalassaemia trait was discovered during the study, one West Indian child, two Africans, one Greek Cypriot, and one child admitted for investigation of anaemia.

Haemoglobin concentration and mean corpuscular volume were compared with age and sex specific reference ranges, ${ }^{34}$ and, along with mean corpuscular haemoglobin and ferritin values, the results were also compared by age, sex, and ethnic group.

Statistical evaluation was by $\chi^{2}$ test and the Mann-Whitney $\mathrm{U}$ test.

\section{Results}

After exclusion of the 14 children noted above, 778 children ( 513 white, 265 from the Asian ethnic minority) were eligible for the study. These corresponded to about $6 \%$ of the children of this age residing in the Bradford Health District.

There were no significant differences in the proportions of boys and girls, in the results between boys and girls in each ethnic group, or for the 
boys as a whole when compared with the girls as a whole. Results are therefore presented irrespective of sex.

Complete results were obtained for 400 children ( $51.4 \%$ ); haemoglobin but not the ferritin value was measured in a further 198 children $(25 \cdot 4 \%)$, most of whom had red cell morphology assessed; and in 180 children $(23 \cdot 1 \%)$ no blood tests were done. Generally, these were children with less serious conditions (table I) - for example, 58 of the 74 children admitted with a history of ingestion were not studied. Children from the Asian ethnic minority were studied more completely.

Haemoglobin concentrations - Both ethnic groups had an excess of children with low haemoglobin values by comparison with the standards (fig 1; table II), the difference being significant $(\mathrm{p}<0.005)$.

Red cell morphology-Red cell haemoglobin and size were lower among the Asian children than among the white children (fig 2; tables III, IV). This

TABLE I-Clinical details of white and Asian children in whom both haemoglobin and ferritin estimations, haemoglobin estimation alone, or no blood tests were performed

\begin{tabular}{|c|c|c|c|c|c|c|}
\hline & \multicolumn{3}{|c|}{ White } & \multicolumn{3}{|c|}{ Asian ethnic minority } \\
\hline & Haemoglobin and ferritin & Haemoglobin & None & Haemoglobin and ferritin & Haemoglobin & None \\
\hline No & 228 & 145 & 140 & 172 & 53 & 40 \\
\hline \multicolumn{7}{|l|}{ Age (years): } \\
\hline Mean & 1.89 & 1.62 & $1 \cdot 79$ & $1 \cdot 64$ & 1.66 & $1 \cdot 70$ \\
\hline SD & 0.96 & 0.96 & $1 \cdot 03$ & 0.90 & $1 \cdot 07$ & 1.03 \\
\hline \multicolumn{7}{|l|}{ Diagnosis "infective": } \\
\hline Serious ${ }^{\star}$ & 6 & 5 & 0 & 6 & 0 & 0 \\
\hline Febrile fit & 25 & 19 & 1 & 26 & 4 & 2 \\
\hline Chest infection & 20 & 16 & 7 & 18 & 8 & 0 \\
\hline Gastroenteritis & 67 & 36 & 52 & 52 & 19 & 15 \\
\hline Other & 30 & 23 & 13 & 20 & 8 & 4 \\
\hline \multicolumn{7}{|l|}{ "Non-infective": } \\
\hline Respiratory illness & 31 & 9 & 3 & 23 & 3 & 3 \\
\hline Ingestion & 6 & 3 & 50 & 4 & 3 & 8 \\
\hline "Social" & 12 & 11 & 3 & 2 & 1 & 2 \\
\hline Neuro/developmental & 16 & 10 & 8 & 7 & i & 5 \\
\hline Other & 15 & 13 & 3 & 14 & 6 & 1 \\
\hline
\end{tabular}

^Meningitis, encephalitis, septicaemia, urinary tract infection.

TABLE II-Distribution of haemoglobin concentrations in the two ethnic groups of children studied

\begin{tabular}{|c|c|c|c|c|c|c|c|c|c|}
\hline & & \multicolumn{7}{|c|}{ Haemoglobin $(\mathrm{g} / \mathbf{l})$} & \multirow[b]{2}{*}{ Total } \\
\hline & & $<90$ & $90-99$ & $100-109$ & $110-119$ & $120-129$ & $130-139$ & $\geqslant 140$ & \\
\hline White & $\left\{\begin{array}{l}\text { No } \\
\%\end{array}\right.$ & $\begin{array}{l}2 \\
0.5\end{array}$ & $\begin{array}{l}5 \\
1 \cdot 3\end{array}$ & $\begin{array}{l}38 \\
10 \cdot 2\end{array}$ & $\begin{array}{l}126 \\
33 \cdot 8\end{array}$ & $\begin{array}{c}134 \\
35 \cdot 9\end{array}$ & $\begin{array}{l}46 \\
12 \cdot 3\end{array}$ & $\begin{array}{l}22 \\
5 \cdot 9\end{array}$ & $\begin{array}{c}373 \\
(100 \cdot 0)\end{array}$ \\
\hline Asian ethnic minority & $\left\{\begin{array}{l}\text { No } \\
\%\end{array}\right.$ & $\begin{array}{l}9 \\
4 \cdot 0\end{array}$ & 12 & $\begin{array}{l}43 \\
19 \cdot 1\end{array}$ & $\begin{array}{l}56 \\
24.9\end{array}$ & $\begin{array}{l}58 \\
25 \cdot 8\end{array}$ & $\begin{array}{l}34 \\
15 \cdot 1\end{array}$ & $\stackrel{13}{5 \cdot 8}$ & $\begin{array}{c}225 \\
(100 \cdot 0)\end{array}$ \\
\hline
\end{tabular}
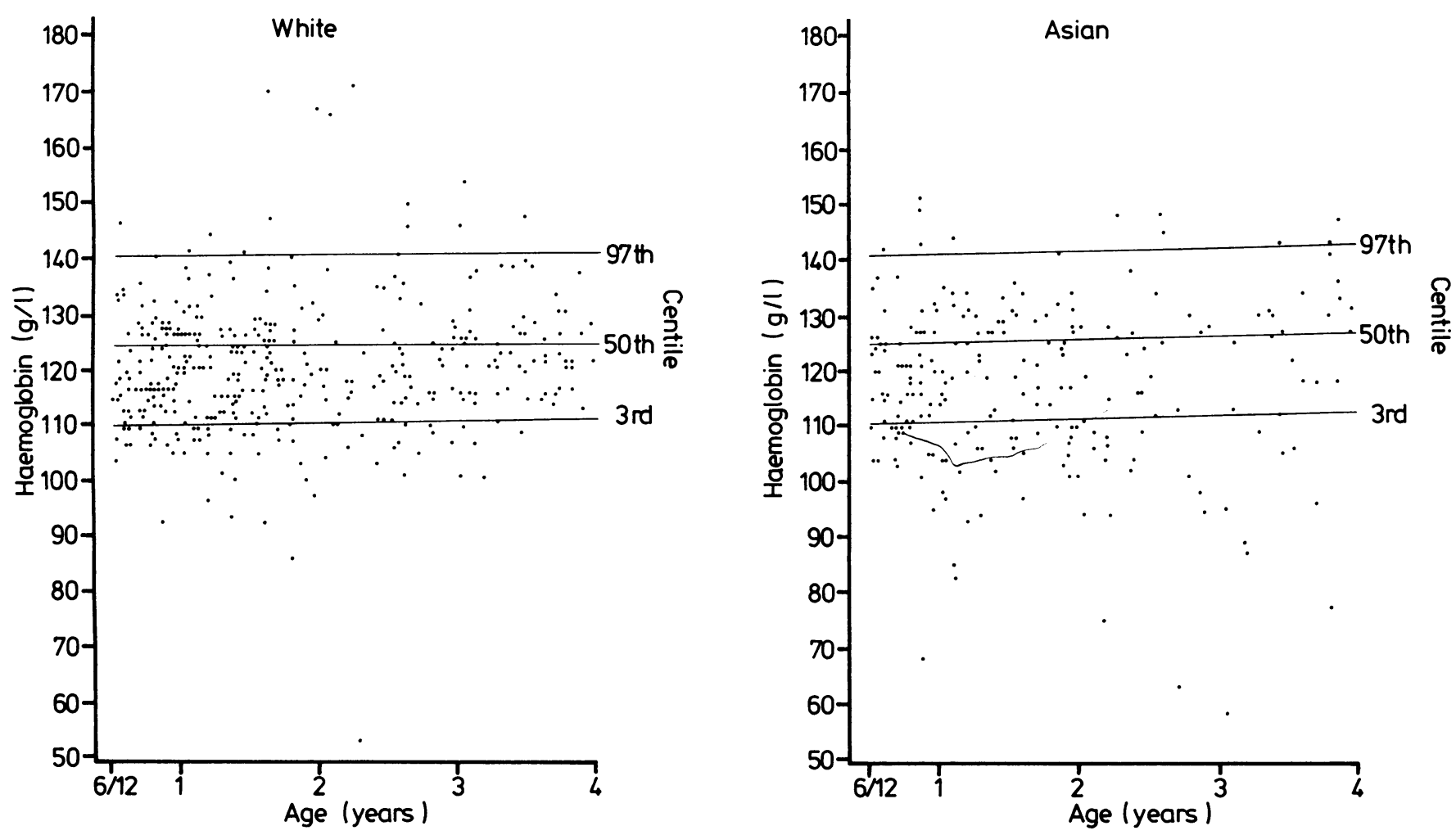

FIG 1-Haemoglobin concentrations distributed by age in the two ethnic groups 
may have been a genetic difference but more probably ${ }^{5}$ was due to the even poorer iron state among those children (see below) whose distribution of red cell size differed significantly from the standards $(p<0.005)$.

Serum ferritin concentrations below $10 \mu \mathrm{g} / 1$ were very common in both groups (table V). Comparison by admission diagnosis showed higher ferritin values among infected children than in those not infected, the difference being significant for the white children $(\mathrm{p}<0.005)$. Infection may have raised the serum ferritin concentrations of some children.

\section{Discussion}

Blood tests were omitted in most of the children (mainly white) admitted for observation with a history of ingestion and in many manifested by anaemia-the incidence being even higher in the Asian children.

Low serum ferritin concentrations reflect iron stores well. Measuring ferritin is unsatisfactory in the assessment of body iron when the serum concentration is high, a frequent finding in inflammation. ${ }^{67}$ Reeves $e t$ al found higher serum ferritin values in 1 year old children when there was a history of recent infection. ${ }^{8}$ Higher serum ferritin concentrations were seen in the study children who presented with infection (table V), and the incidence of iron deficiency reported here is probably an underestimate, particularly for the white children.

That iron deficiency is common in young children, more so in the underprivileged, ${ }^{9 \cdot 12}$ is well known. Even in the absence of anaemia

TABLE III-Distribution of mean corpuscular haemoglobin values in the two ethnic groups of children studied

\begin{tabular}{|c|c|c|c|c|c|c|c|c|}
\hline & & \multicolumn{6}{|c|}{ Mean corpuscular haemoglobin (pg) } & \multirow[b]{2}{*}{ Total } \\
\hline & & $<20.0$ & $20 \cdot 0-21 \cdot 9$ & $22 \cdot 0-23 \cdot 9$ & $24 \cdot 0-25 \cdot 9$ & $26 \cdot 0-27 \cdot 9$ & $\geqslant 28.0$ & \\
\hline White & $\left\{\begin{array}{l}\text { No } \\
\%\end{array}\right.$ & $\begin{array}{l}1 \\
0 \cdot 3\end{array}$ & $\begin{array}{l}3 \\
0.9\end{array}$ & $\begin{array}{c}20 \\
5 \cdot 7\end{array}$ & $\begin{array}{l}104 \\
29 \cdot 5\end{array}$ & $\begin{array}{c}136 \\
38.6\end{array}$ & $\begin{array}{l}88 \\
25 \cdot 0\end{array}$ & $\begin{array}{c}352 \\
(100 \cdot 0)\end{array}$ \\
\hline Asian ethnic minority & $\left\{\begin{array}{l}\text { No } \\
\%\end{array}\right.$ & $\begin{array}{l}31 \\
14 \cdot 4\end{array}$ & $\begin{array}{l}30 \\
13.9\end{array}$ & $\begin{array}{l}45 \\
20 \cdot 8\end{array}$ & $\begin{array}{l}58 \\
26 \cdot 9\end{array}$ & $\begin{array}{l}43 \\
19 \cdot 9\end{array}$ & $\begin{array}{l}9 \\
4 \cdot 2\end{array}$ & $\stackrel{216}{(100 \cdot 0)}$ \\
\hline
\end{tabular}

TABLE IV-Distribution of mean corpuscular volumes in the two ethnic groups of children studied

\begin{tabular}{|c|c|c|c|c|c|c|c|c|c|}
\hline & & \multicolumn{7}{|c|}{ Mean corpuscular volume $(\mathbf{f})$} & \multirow[b]{2}{*}{ Total } \\
\hline & & $<60$ & $60-64$ & $65-69$ & $70-74$ & $75-79$ & $80-84$ & $\geqslant 85$ & \\
\hline White & $\left\{\begin{array}{l}\text { No } \\
\%\end{array}\right.$ & $\begin{array}{l}0 \\
0\end{array}$ & $\begin{array}{l}1 \\
0.3\end{array}$ & $\begin{array}{l}6 \\
1 \cdot 7\end{array}$ & $\begin{array}{l}52 \\
14 \cdot 8\end{array}$ & $\begin{array}{c}146 \\
41 \cdot 5\end{array}$ & $\begin{array}{c}107 \\
30 \cdot 4\end{array}$ & $\begin{array}{l}40 \\
11 \cdot 4\end{array}$ & $\begin{array}{c}352 \\
(100 \cdot 0)\end{array}$ \\
\hline Asian ethnic minority & $\left\{\begin{array}{l}\text { No } \\
\%\end{array}\right.$ & $\begin{array}{l}22 \\
10 \cdot 2\end{array}$ & $\begin{array}{l}24 \\
11 \cdot 1\end{array}$ & $\begin{array}{l}39 \\
18 \cdot 1\end{array}$ & $\begin{array}{l}46 \\
21 \cdot 3\end{array}$ & $\begin{array}{l}60 \\
27 \cdot 8\end{array}$ & $\begin{array}{l}20 \\
9 \cdot 3\end{array}$ & $\begin{array}{l}5 \\
2 \cdot 3\end{array}$ & $\stackrel{216}{(100 \cdot 0)}$ \\
\hline
\end{tabular}

Conversion: SI to traditional units-Mean corpuscular volume: $1 \mathrm{fl}=1 \mu \mathrm{m}^{3}$.

TABLE V_Distribution of serum ferritin concentrations above and below $10 \mu \mathrm{g} / \mathrm{l}$ in white and Asian children with and without infection on admission

\begin{tabular}{|c|c|c|c|c|c|c|}
\hline & \multicolumn{3}{|c|}{ White } & \multicolumn{3}{|c|}{ Asian ethnic minority } \\
\hline & "Infective" & "Non-infective" & Total & "Infective" & "Non-infective" & Total \\
\hline \multicolumn{7}{|c|}{ Ferritin $(\mu \mathrm{g} / \mathrm{l})$ : } \\
\hline$<10$ & 25 & 28 & $53(23 \cdot 2 \%)$ & 55 & 23 & $78(45 \cdot 3 \%)$ \\
\hline$\geqslant 10$ & 123 & 52 & $175(76 \cdot 8 \%)$ & 67 & 27 & $94(54 \cdot 7 \%)$ \\
\hline Total & 148 & 80 & $228(100 \cdot 0 \%)$ & 122 & 50 & $172(100 \cdot 0 \%)$ \\
\hline \multicolumn{7}{|l|}{ Centile: } \\
\hline 97 th & $79 \cdot 0$ & $48 \cdot 0$ & $78 \cdot 0$ & $74 \cdot 0$ & $80 \cdot 0$ & $77 \cdot 3$ \\
\hline 75 th & $37 \cdot 0$ & $22 \cdot 9$ & $33 \cdot 6$ & $31 \cdot 0$ & $25 \cdot 0$ & $29 \cdot 0$ \\
\hline 50 th & $25 \cdot 8$ & $13 \cdot 1$ & $20 \cdot 0$ & $13 \cdot 6$ & $12 \cdot 4$ & $13 \cdot 1$ \\
\hline 25 th & $16 \cdot 0$ & 8.9 & $11 \cdot 0$ & $5 \cdot 4$ & $<4 \cdot 0$ & $4 \cdot 8$ \\
\hline 3 rd & $<4 \cdot 0$ & $<4 \cdot 0$ & $<4 \cdot 0$ & $<4 \cdot 0$ & $<4 \cdot 0$ & $<4 \cdot 0$ \\
\hline
\end{tabular}

white children with gastroenteritis. In all diagnostic categories there was a tendency to more complete studies in the children from the Asian ethnic minority, two thirds of whom were studied fully, compared with less than half of the white children. This may have reflected a greater willingness by the admitting doctors to recognise the possibility of iron deficiency in the Asian children.

The 598 children whose haemoglobin concentration was measured represented over $4 \%$, and the 400 whose serum ferritin value was assayed some $3 \%$, of their age group resident in the Bradford Health District. The results obtained in this study may reflect results obtainable in children from the poorer sections of society. One in three of the children had a serum ferritin concentration below $10 \mu \mathrm{g} / \mathrm{l}$, indicating very poor iron stores-in some cases people with iron deficiency perform poorly,,$^{13}$ both mentally ${ }^{10}$ and physically. ${ }^{14}$ Most iron deficiency in childhood has a dietary origin. ${ }^{15-17}$ Whole cows' milk may additionally cause gastrointestinal bleeding in some infants. ${ }^{18}$ Good diet and the prevention of iron deficiency is the appropriate management. Prophylactic oral iron supplementation is generally recommended for children born small, whether preterm or small for gestational age. ${ }^{19}$

These findings show how useful is a "routine" full blood count in young children admitted to hospital, whatever their ethnic origin, in providing important information about the iron state of a substantial minority. Scrutinising the results for anaemia and microcytosis, relating values to appropriate standards for age, yields a presumptive diagnosis of iron deficiency. ${ }^{20}$ In populations where 

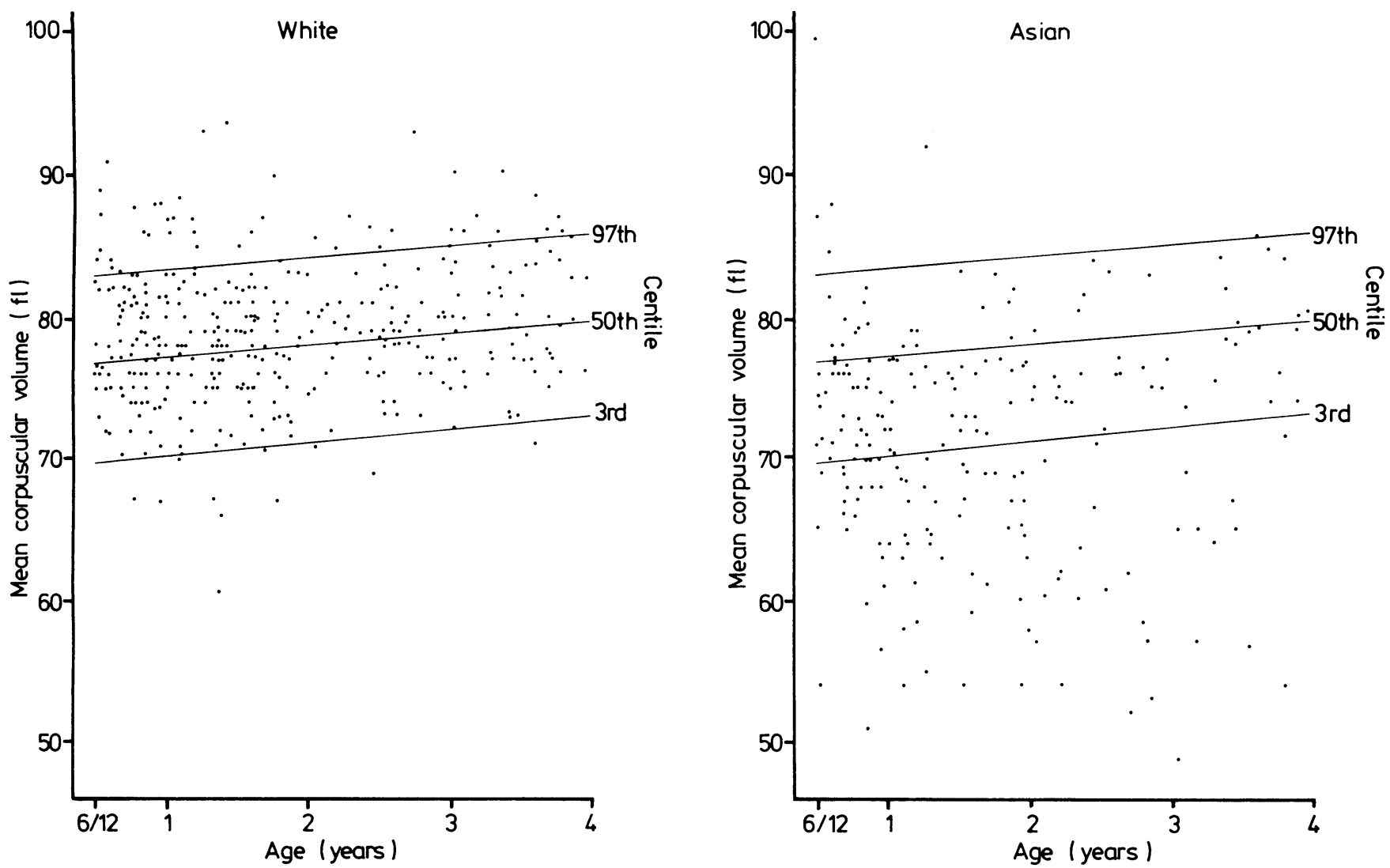

FIG 2-Mean corpuscular volumes distributed by age in the two ethnic groups of children studied.

$\beta$ thalassaemia is common this should be excluded if hypochromia and microcytosis are severe. Oral iron may be prescribed, $2 \mathrm{mg} / \mathrm{kg}$ daily being given for two months, and the full blood count rechecked. Failure of the microcytosis to improve mandates that iron state should be assessed. Possible reasons include noncompliance, inadequate dosage, or persistent occult bleeding as well as an occasional child, severely iron deficient, who will respond only to parenteral iron. ${ }^{21}$

It has been suggested that iron supplementation in young children may promote bacterial infection. There is some in vitro evidence that iron excess promotes the growth of bacterial pathogens such as Escherichia coli, ${ }^{22}$ while large doses of parenteral iron given prophylactically to Polynesian neonates were associated with increased mortality. ${ }^{23}$ There is no convincing evidence that iron deficiency benefits children. Bondestam et al found that Swedish children unduly susceptible to infection had lower serum iron concentrations. ${ }^{24}$ Giving a nutritional supplement including iron to rural Colombian children produced an impressive reduction in infectious disease. ${ }^{25}$ It appears that community-wide feeding programmes can virtually eliminate iron deficiency. ${ }^{9}$ In Britain children from higher socioeconomic groups suffer less mortality and probably morbidity than those from poorer groups. ${ }^{26}$ Oral iron may safely be administered in the dosage recommended and should not be omitted on account of theoretical worries about infection.

Iron deficiency, though commoner, is not restricted to the Asian ethnic minority children, being found in a quarter of the white children. The Stop Rickets Campaign has been highly successful, while the Women, Infants, and Children programme of supplementary feeding in the United States has reduced the incidence of childhood iron deficiency. ${ }^{9}$ The extent and degree of iron deficiency reported here are such that a similar active intervention programme should be considered.

Thanks are due to the children and their families, to the hospital staff who obtained the blood samples, to the Bradford paediatricians and haematologists, and to Dr B Payne and Dr A D Claydon.

\section{References}

1 Hallberg L. Iron absorption and iron deficiency. Hum Nutr Clin Nutr 1982;36C:259-78.

2 Charlton RW, Bothwell TH. Iron absorption. Annu Rev Med 1983;34:55-68.

3 Saarinen UM, Siimes MA. Developmental changes in red blood cell counts and indices of infants after exclusion of iron deficiency by laboratory criteria and continuous iron supplementation. $\mathcal{J}$ Pediatr 1978;92:412-6.

4 Dallman PR, Siimes NA. Percentile curves for hemoglobin and red cell volume in infancy and childhood. I Pediatr 1979;94:26-31.

5 Reeves JD, Driggers DA, Lo EYT, Dallman PR. Screening for anemia in infants: evidence in favor of using identical hemoglobin criteria for blacks and Caucasians. Am 7 Clin Nutr 1981;34:2154-7.

6 Lipschitz DA, Cook JD, Finch CA. A clinical evaluation of serum ferritin as an index of iron stores. N Engl F Med 1974;290:1213-6.

7 Deinard AS, Schwartz S, Yip R. Developmental changes in serum ferritin and erythrocyte protoporphyrin in normal (nonanemic) children. Am $\mathcal{f}$ Clin Nutr 1983;38:71-6.

8 Reeves JD, Yip R, Kiley VA, Dallman PR. Iron deficiency in infants: the influence of mild antecedent infection. F Pediatr 1984;105:874-9.

9 Miller V, Swaney S, Deinard A. Impact of the WIC program on the iron status of infants. Pediatrics 1985; 75:100-5.

10 Oski FA, Honig AS, Helu B, Howanitz P. Effect of iron therapy on behavior performance in nonanemic, iron-deficient infants. Pediatrics 1983;71:877-80

11 Savilahti E, Simell O. Chronic non-specific diarrhoea. Arch Dis Child 1985;60:452-6.

12 Brault-Dubuc M, Nadeau M, Dickie J. Iron status of French Canadian children: a three year follow up study. Hum Nutr Appl Nutr 1983;37A:210-21.

13 Oski FA. The nonhematologic manifestations of iron deficiency. Am J Dis Child 1979;133:315-22.

14 Schoene RB, Escourrou P, Robertson HT, Nilson KL, Parsons JR, Smith NJ. Iron repletion decreases maximal exercise lactate concentrations in female athletes with minimal iron deficiency anemia. f Lab Clin Med 1983;102:306-12.

15 Dallman PR, Siimes MA, Stekel A. Iron deficiency in infancy and childhood. Am $\mathcal{J}$ Clin Nutr 1980;33:86-1116

16 Sadowitz PD, Oski FA. Iron status and infant feeding practices in an urban ambulatory center. Pediatrics 1983;72:33-6.

17 Committee on Nutrition of the American Academy of Pediatrics. Iron supplementation for infants. Pediatrics 1976;58:765-8

18 Fomon SJ, Ziegler EE, Nelson SE, Edwards BB. Cow milk feeding in infancy: gastrointestinal blood loss and iron nutritional status. $\mathcal{F}$ Pediatr 1981;98:540-5.

19 Siimes MA. Iron requirement in low birthweight infants. Acta Paediatr Scand 1982;supp 296: 101-3.

20 Knight GJ, Heese HdeV, Dempster WS, Kirsten G. Diagnosis of iron deficiency: mean corpuscular hemoglobin as a predictor of iron deficiency in infants. Pediatr Res 1982;16:168-70.

21 Oski FA, Stockman JA. Anemia due to inadequate iron sources or poor iron utilization. Pediat Clin North Am 1980;27:237-52.

22 van Asbeck BS, Verhoef J. Iron and host defence. Eur f Clin Microbiol 1983;2:6-10.

23 Barry DMJ, Reeve AW. Increased incidence of Gram-negative neonatal sepsis with intramuscular iron administration. Pediatrics 1977;60:908-12.

Bondestam M, Foucard T, Gebre-Medhin M. Subclinical trace element deficiency in children with undue susceptibility to infections. Acta Paediatr Scand 1985;74:515-20.

25 Lukens JN. Iron deficiency and infection: fact or fable? Am f Dis Child 1975;129:160-2.

26 Department of Health and Social Security. Inequalities in health. London: HMSO, 1980. (Black report.)

(Accepted 23 October 1985) 